Article

\title{
Challenge of Doing Catholic Ethics in a Pluralistic Context
}

\section{Shaji George Kochuthara}

Department of Moral Theology, Faculty of Theology, Dharmaram Vidya Kshetram, Bangalore 560029, India; kochuthshaji@gmail.com

Received: 24 October 2019; Accepted: 24 December 2019; Published: 29 December 2019

\begin{abstract}
The article discusses the possibility of doing Catholic ethics in a religiously and culturally pluralistic context. Beginning with the possibility of pluralistic approach in Catholic ethics, the article refers to the Indian context as an example for the discussion. Particularly it takes two issues-ecological ethics and sexual ethics - to reflect on the need and possibility of doing Catholic ethics in a pluralistic context. Although the arguments here may be applicable to other contexts of pluralism, the article mainly points out examples from the Indian contexts. The discussion here is basically from a Catholic perspective, namely, why Catholics should be open to different sources and approaches in ethics, and how they can work together with others in identifying common grounds for ethics. Although a few guidelines for constructing a pluralistic ethics are indicated, the attempt is not to propose a framework for such an ethics, but mainly to show the need and possibility of such an ethics.
\end{abstract}

Keywords: catholic ethics; hindu ethics; natural law; human rights; culture; inculturation; interculturation

\section{Introduction: Plurality-A Reality of Life}

Pluralism is a reality of life today. Pluralism "refers to "a situation in which a variety of viewpoints, explanations or perspectives are offered as accounting for the same reality" (Henn 1987, p. 770). Pluralism extends to various realms—religious, cultural, philosophical, social, ethnic, linguistic, and so on. In fact, pluralism existed always, but today we are more intensely aware of pluralism and its all-encompassing nature. Even a few decades back, the West was not considered basically pluralistic. Although various religions and cultures had their presence in the West, they were not predominant in the society as a whole; Christianity was considered the religion of the West. With globalization and drastic migration, this has changed very fast in recent decades. The number of people in the West belonging to other religions and cultures and ethnic groups is no more insignificant. Many of these religions have organized networks, places of worship, and organizations in many Western countries. Moreover, we acknowledge that pluralism will remain as a reality of life. An ever-increasing pluralism is inevitable and irreversible. "Today we are aware of the sources of pluralism: the mystery of God, the complexity of reality, infinite possibility and diversity of the human subject, limitations and historicity of human points of view and the differences in the objective world or context" (Pathil 2014, p. 326). The world today witnesses to diverse religious, theological, philosophical, ethical, ideological, and cultural systems and theories and their corresponding various practices (Pathil 2014, p. 327). However, our plural world is not contradictory, but complementary, mutually challenging, and enriching (Tracy 1975). At the same time, "Pluralism does not mean relativism or religious indifferentism or self-sufficiency, as pluralism has to go hand in hand with unity, the centripetal force of this universe" (Pathil 2014, p. 327). But, instead of an 'either-or' concept, pluralism stands for 'both-and'.

Beginning with the possibility of pluralistic approach in Catholic ethics, I shall refer to the Indian context as an example for our discussion. Although the arguments here may be applicable to other 
contexts of pluralism, I shall mainly point out examples from the Indian contexts. We shall particularly take two issues-ecological ethics and sexuality-to reflect on the need and possibility of doing Catholic ethics in a pluralistic context. Our discussion here is basically from a Catholic perspective, namely, why as Catholics we should be open to different sources and approaches in ethics, and how we can work together with others in identifying common grounds for ethics. Although we attempt to draw some conclusions and guiding principles for developing a pluralistic approach to ethics, within the limited scope of this article, we do not propose a new theory of pluralistic approach to ethics, but shall focus more on the possibility and need of developing such an approach.

\section{Pluralistic Context of India}

India is a land of religious pluralism. For example, according to 2011 census, in India, Christianity is a small minority with $2.3 \%$; Hindus are $79.8 \%$, Muslims are $14.23 \%$, and Sikhs are $1.72 \%$. Besides this, though small in number, Buddhism, Jainism, and many other religions continue to exert great influence in the Indian society (Census of India 2011a). Though in our discussions, we shall consider mainly religious pluralism in India, we cannot ignore other aspects of pluralism. In India there is a confluence of various cultures-Dravidic, Aryan, Subaltern, Tribal, etc. Moreover, each state or region can be said to have different culture or even cultures. There are various races-six main races with sub-races. There are also many languages-there are 22 official languages and thousands of dialects (Census of India 2011b). All these add to the complexity of the pluralistic nature of India. Besides this, there is a revival of Hinduism, which has also taken fundamentalist trends as well. Although prohibited by law, to a great extent the society continues to be hierarchical based on castes and sub-castes. In fact, with the prominence that right-wing groups have gained in Indian politics and society, there is an attempt to revive caste system, though not officially, as indicated by a sharp increase in the number of attacks on lower castes by higher castes. Furthermore, we have to consider the changing lifestyle influenced by globalization and neo-liberal economy. Economic condition also varies. Though India is already considered one of the economic powers of the world, even according to the most optimistic statistics, there are at least 350 million people living under the poverty line.

Developments in civil law highlight another aspect of the complexities in moral matters. Interventions by the court or legal system in ethical matters have been on the increase. This is based on the constitution of the country, irrespective of religious affiliation, considering all citizens equal, having equal rights and responsibilities. For example, on 22 August 2017, the Supreme Court of India declared unconstitutional the Islamic practice of Triple Talaq (Triple Talaq in India n.d.; The Guardian 2019). The Supreme Court verdict decriminalising homosexuality was also widely discussed. Similarly, the court verdict on LGBT/Transgender (Plathottam 2009), Pre-marital sex (Times of India 2010), extra-marital sex (Vaidyanathan 2018; Singh 2018), etc., raised mixed responses. In the past, such matters would be left to the discretion of the religions, as belonging to religious ethics. Or, take the case of court ruling permitting entry of young women into the Sabarimala temple (Economic Times 2018). The court is considering a case on Muslim women's entry into mosques, on the ground of equal rights of women. This is only one of the dilemmas that we face in ethical consideration today, namely, where the constitutional or legal morality and religious morality may come in conflict, or where they may differ. On the other hand, morality may differ according to religion and culture. This we have experienced always. However, this difference is sharply felt today, and sometimes they lead to conflicts. In such situations, how can we dialogue with others and live in harmony and peace?

\section{Possibility of Pluralistic Approach in Ethics}

The 20th century marked a greater awareness from the part of the Church of pluralism, the relative nature of the cultural and conceptual frames in which faith was expressed and, hence, a greater openness towards other cultures and philosophical traditions. This can be noticed in the Second Vatican Council documents, especially in Nostra Aetate and in the subsequent attitude of the Church 
towards other cultures and philosophical traditions, making interreligious dialogue and inculturation one of the major themes of theological discussions.

On the one hand, we say that Christianity from the beginning attempted to inculturate its message, to make the Gospel intelligible to the peoples imparting it through their languages and conceptual frameworks and dialoguing with their cultures and beliefs, accepting the presence of truth in them. On the other hand, attempts on the opposite direction also can be seen and in certain periods of history, for example, judging other cultures and religions as the work of the devil and considering Christianity as the sole depository of truth and salvation. Evidently, today we have come far from such negative and judgmental attitudes. However, hesitations, apprehensions, and precautions surround inculturation and, hence, in spite of positive efforts, determined and definite steps are yet to be taken. There is also resistance towards inculturation, not only from the Western Church, but also from the Asian and African Churches. Yet, others point out that even the term "inculturation" has an implication of superiority and domination and, hence, we should think in terms of inter-culturation (Chackalackal 2016, pp. 400-2). Similarly, many observe that together with the age-old traditional cultures, the new post-modern culture of globalization is also to be taken into account for inculturation; that is, inculturation cannot be limited to the cultural heritage of the past, but should be sensitive to the changed and changing cultural patterns (Painadath 2016, pp. 467-8). In spite of a variety of opinions, innumerable apprehensions, and lack of clarity of the precise steps to be taken, there is a growing awareness of the need of a more open, sincere, and profound dialogue with different religious and cultural traditions.

At the same time, we can also notice trends in the opposite direction, namely, strengthening of fundamentalist ideas within the Catholic Church itself. Such trends are visible in other religions as well. Furthermore, in spite of a greater openness to dialogue with various religious and cultural traditions, when it comes to ethics, the scenario looks different. Dialogue in ethics and openness to different ways of approaching ethics or ethical issues have not been much visible much in Christian ethics. Christian response to ethical matters/issues has been rather rigid and monolithic. Uniformity of thinking and practice in ethical matters have been the Christian response, based on the argument that they are clear to all people of good will, that they are proved by revelation and reason. That is, only Catholic understanding was considered correct, and it was taken for granted. Hence, the question is pertinent: Is pluralism possible in Catholic ethics? Can Catholic ethics accept pluralistic approaches? Can ethical norms different from the Catholic be considered salvific? Though much progress has not been made in pluralistic ethics, we can find that Catholic tradition offers various possibilities of developing pluralistic approaches in ethics.

\subsection{Nostra Aetate and Subsequent Documents of the Church}

As mentioned above, from Nostra Aetate we find a definite change in the Church's approach to other religions. Acknowledging that the Catholic Church "rejects nothing of what is true and holy in these religions" and that the Church has a "high regard for the manner of life and conduct" of these religions, the Council urges the members of the Church to enter into dialogue with other religions. Moreover, the Council urges Christians to "acknowledge, preserve and encourage the spiritual and moral truths found among non-Christians, also their social life and culture" (Vatican II 1965, para. 2). We cannot consider spiritual and moral life as two compartments. By acknowledging the spiritual value of other religions, the Council is also acknowledging the value of their moral wisdom and practice, though there can be differences. This openness in dialogue is continued in the subsequent documents of the Church. For example, John Paul II's Fides et Ratio, particularly article 72, explicitly speaks about the "new tasks of inculturation." The Pope speaks in detail of the "duty" of Christians in India "to draw from this rich heritage the elements compatible with their faith, in order to enrich Christian thought" (John Paul II 1998, para. 72). Though the Pope delineates certain criteria for the task of inculturation, the focus is not on precautions to be taken, but on the openness to other cultural and philosophical traditions. The Pope also clearly states that what is said about India is true regarding the great traditions of China, Japan, other Asian countries. and Africa (John Paul II 1998, para. 72). 
Another example is the Synod of Bishops for Asia and particularly its final message: "We gladly acknowledge the spiritual values of the great religions of Asia such as Hinduism, Buddhism, Judaism, Islam ... We esteem the ethical values in the customs and practices found in the teachings of the great philosophers of Asia, which promote natural virtues and pious devotion to ancestors. We also respect the beliefs and religious practices of indigenous/tribal people, whose reverence for all creation manifests their closeness to the Creator" (UCA.News 1998).

For a long time, the Federation of Asian Bishops' Conferences (FABC) has focused on triple dialogue, considering the three main Asian realities of life: Dialogue with the vibrant religious traditions, ancient cultures, and teeming millions of Asian poor (Eilers 1997, p. 2).

\subsection{Natural Law Tradition}

Natural law tradition has been one of the major foundations of Catholic ethics. According to the concept of natural law, human beings can understand moral norms through the use of reason. This points to the God-given capacity that all human beings possess, irrespective of religious affiliation. That is, there is no contradiction between faith and reason, since reason itself is understood as the supreme gift of God. In the West, the origin of the natural law concept can be traced back to the Greek philosophical tradition. The Christian Fathers and theologians who made use of Greek philosophy to expound Christian faith, made use of the natural law concept as well. Thomas Aquinas developed this concept further, giving a solid foundation to the natural law concept in the Christian tradition (Thomas Aquinas 1947, pp. 90-108). In recent decades, there have been attempts to make use of the natural law concept to think about common foundations for ethics, and to promote interreligious and intercultural communication and consensus on ethical norms and issues. Following a series of interreligious and intercultural discussions on natural law in various continents, initiated by the Congregation for the Doctrine of the Faith, the International Theological Commission has published a document, In Search of a Universal Ethic: A New Look at the Natural Law (2009), which discusses in detail how the wisdom traditions and religions, though they may vary considerably, testify to the patrimony of moral values. At the very outset, the document shows the need for thinking together about common ethical standards:

"Are there objective moral values which can unite human beings and bring them peace and happiness? What are they? How are they discerned? How can they be put into action in the lives of persons and communities? These perennial questions concerning good and evil are today more urgent than ever, insofar as people have become more aware of forming one single world community. The great problems that arise for human beings today have an international, worldwide dimension, inasmuch as advances in communications technology have given rise to closer interaction among individuals, societies and cultures" (International Theological Commission 2009, para. 1).

The document acknowledges that in "diverse cultures, people have progressively elaborated and developed traditions of wisdom in which they express and transmit their vision of the world"; these wisdom traditions, which are often of a religious nature, convey an experience of what favors and what hinders the full blossoming of personal life and the smooth running of social life; they are "cultural capital" available "in the search for a common wisdom necessary for responding to contemporary ethical challenges." It is also acknowledged that these traditions reflect the divine wisdom (International Theological Commission 2009, para. 12).

In Search of a Global Ethic delineates the ethical traditions and contributions of various religions: In the Hindu traditions, the cosmos and human societies are regulated by dharma, an order or fundamental law, which one must respect in order not to cause serious imbalances. Dharma defines the socio-religious obligations of humans; good and bad actions and their consequences; the importance of disinterested action for the benefit of others; the importance of non-violence (ahims $\bar{a})$. It is also pertinent to note how In Search of a Universal Ethic cites an equivalent principle of the golden rule:

"I will tell you what is the essence of the greatest good of the human being. The man who practices the religion (dharma) of do no harm to anyone without exception (ahims $\bar{a})$ acquires the greatest good. 
This man is the master of the three passions: cupidity, anger and avarice, and renouncing them in relation to all that exists, acquires success.... This man who considers all creatures like 'himself' and treats them as his own 'self', laying down the punishing rod and dominating his anger completely, assures for himself the attainment of happiness.... One will not do to another what one considers harmful to oneself. This, in brief, is the rule of virtue.... In refusing and in giving, in abundance and in misery, in the agreeable and the disagreeable, one will judge all the consequences by considering one's own 'self'" (International Theological Commission 2009, para. 13). "Several precepts of the Hindu tradition can be placed in parallel with the requirements of the Decalogue" (International Theological Commission 2009, para. 13). ${ }^{2}$

Following this, In Search of a Universal Ethic elaborates upon the noble truths in Buddhism and the five precepts and states: "The profound altruism of the Buddhist tradition, which is expressed in a resolute attitude of non-violence, amicable benevolence and compassion, thus agrees with the golden rule" (International Theological Commission 2009, para. 14). Islamic understanding also facilitates seeking common ground for ethics: "The Islamic ethic is, therefore, fundamentally a morality of obedience. To do good is to obey the commandments; to do evil is to disobey them" (International Theological Commission 2009, para. 17).

Here, our main concern is not to describe common teachings of various religions; rather, we shall point out the possibility of developing common ethical standards utilizing the natural law tradition, which has been so important in the Catholic tradition. Here, we have to also remember what many contemporary ethicists have often pointed out, namely, natural law is cultural, historical, experiential, proportional, and contextual (Gula 1989, pp. 242-6). This provides the possibility of variety and openness to different approaches. Moreover, Amoris Laetitia, Post-Synodal Apostolic Letter on the Joy of Love by Pope Francis, highlights an important aspect in the natural law theory of Thomas Aquinas:

"'Although there is necessity in the general principles, the more we descend to matters of detail, the more frequently we encounter defects ... In matters of action, truth or practical rectitude is not the same for all, as to matters of detail, but only as to the general principles; and where there is the same rectitude in matters of detail, it is not equally known to all ... The principle will be found to fail, according as we descend further into detail' (Thomas Aquinas 1947, q. 94, art. 4). It is true that general rules set forth a good which can never be disregarded or neglected, but in their formulation they cannot provide absolutely for all particular situations" (Francis 2016, para. 304). This again underlines the possibility of different approaches and variety of applications in ethical issues. In other words, based on the same natural law thinking, different religions and cultures may arrive at different conclusions, which are valid. This does not mean that all conclusions are equally correct. Everyone has the responsibility of reflecting on one's own conclusions through dialogue and to correct what is needed, and to seek possibilities of working together for a better ethical response.

\subsection{Declaration of Human Rights}

The Universal Declaration of Human Rights (UDHR) (Universal Declaration of Human Rights n.d.) in 1948 by the UN is yet another example of how we can work together for a common ground in a pluralistic context. Though it is not the first time that human rights are defined, ${ }^{3}$ UDHR can be said to

1 Referring to Mahābhārata, Anusasana parva, 113, 3-9 (ed. Ishwar Chundra Sharma and O.N. Bimali; translation according to M. N. Dutt [Parimal Publications, Delhi], vol. IX, p. 469), as cited in In Search of a Universal Ethic.

2 See footnote 10 in the document: For example: "Let him say what is true, let him say what is pleasing, let him declare no disagreeable truth, and let him utter no lie to please someone; such is the eternal law" (Mānava dharmaśāstra, 4, 138, p. 101); "Let him always consider the action of striking a blow, reviling, and harming the good of one's neighbour, as the three most pernicious things in the string of vices produced by wrath" (Mānava dharmaśăstra, 7, 51, p. 156).

3 Historical sources for bills of rights include the Magna Carta (1215), the English Bill of Rights (1689), the French Declaration of the Rights of Man and the Citizen (1789), and the Bill of Rights in the United States Constitution (1791). Early philosophical sources of the idea of human rights include Francisco Suarez (1548-1617), Hugo Grotius (1583-1645), Samuel Pufendorf (1632-1694), John Locke (1632-1704), and Immanuel Kant (1724-1804). Following UDHR, and based on it, there are many 
be the most comprehensive and most widely accepted document on human rights. It is not easy to give a precise definition of human rights. Broadly, we can say that, "human rights are those claims that belong to the human person as a human person, based on what he/she is" (Kusumalayam 2008, p. 43). That is, all men and women, without any discrimination, irrespective of sex, age, race, nationality, wealth, religion, language, ideology, etc., have these rights. "Human rights are rights inherent to all human beings, regardless of race, sex, nationality, ethnicity, language, religion, or any other status" (Universal Declaration of Human Rights n.d.). Human rights include the right to life and liberty, freedom from slavery and torture, freedom of opinion and expression, the right to work and education, etc. The Preamble of UDHR says, "Whereas the peoples of the United Nations have in the Charter reaffirmed their faith in fundamental human rights, in the dignity and worth of the human person and in the equal rights of men and women and have determined to promote social progress and better standards of life in larger freedom ... " (Universal Declaration of Human Rights n.d.). Though it may be considered as a secular document, without any direct reference to any religion, scholars have pointed out that religious traditions have contributed to the declaration of human rights (Christiansen 2018, pp. 244-45).

UDHR is an example of the achievement of dialogue in ethical matter in a pluralistic context. It shows that in spite of differences, there is the possibility of working together on ethical issues. ${ }^{4}$

\subsection{Development/Change in Ethical Norms}

Various authors have expounded the development in moral doctrine. In an article published in Theological Studies in 1993, John T. Noonan, Jr. highlighted some of the developments in moral doctrine (Noonan 1993), as against the popularly held (mis)conception that moral doctrines never change. Later, in his book, A Church that can and cannot Change: The Development of Catholic Moral Teaching, he has developed further his arguments (Noonan 2005). Some of the areas where we can notice development in moral doctrine are usury, marriage, slavery, religious freedom, etc. Analyzing these developments, Noonan concludes that "In each case one can see the displacement of a principle or principles that had been taken as dispositive." Besides, "these principles were replaced by principles already part of Christian teaching." He also points out that "In the course of this displacement of one set of principles, what was forbidden became lawful (the cases of usury and marriage); what was permissible became unlawful (the case of slavery); and what was required became forbidden (the persecution of heretics)" (Noonan 1993, p. 669). Another important work that discusses in detail the changes in official catholic moral teaching is the edited work by Charles E. Curran (Curran 2003).

Evidently, I do not intend to describe the developments in the moral doctrine or analyze them. I would like to point out that at no point of time can we claim an absolutely definite understanding of moral norms, at least on certain issues. This demands that we do not make absolute claims, and that we do not condemn different ethical positions as unethical; instead, we need to critically evaluate our own positions, being open to other positions, with humility and willingness to learn and to change.

\subsection{Context}

Theology, especially theological ethics, is contextual. Ethics develops in constant communication and dialogue with the context. The complexity of the context in ethics is not only that of different questions, different sources, different approaches, but also of different answers (Kochuthara 2011, p. 298).

human rights documents and treaties such as the United Nations, the Council of Europe, the Organization of American States, and the African Union.

4 The concept of human rights and recognition of the equal rights of all (at least in on some basic matters) are incorporated into the constitutions of various nations. Yet, the concept of human rights may be different in a theocratic nation or a monarchy. Moreover, we cannot say that the concept of human rights is the same everywhere. For example, in some societies, human rights are understood more in terms of the rights of the tribe or community rather than the rights of the individual. Though we do not enter into a detailed discussion on this, it is good to remember that different understandings of human rights continue to exist. This also implies the possibility and need of continuing dialogue on this. 
Instead of becoming exclusive or claiming superiority, what is needed is creative communication and self-critical dialogue among the different approaches in theological ethics. This is one of the tasks that moral theologians need to take up in future with renewed enthusiasm and openness. Here, the dialectical relationship between culture and morality, the growing awareness, and acceptance of religious pluralism as a given context that will continue to exist, and the dialectics between local and global concerns get more attention (Keenan 2007, pp. 101-45).

\subsection{Culture and Inculturation in Ethics}

"Culture concerns the totality of life" (O'Collins 2011, p. 339). Culture is a living reality in a continuous process of change. It is pertinent to see what In Search of a Universal Ethic says about culture and the role of culture in ethics: "Oriented by the persons who surround him [sic], permeated by the culture in which he [sic] is immersed, the person recognizes certain ways of behaving and of thinking as values to pursue, laws to observe, examples to imitate, visions of the world to accept. The social and cultural context thus exercises a decisive role in the education in moral values" (International Theological Commission 2009, para. 38). The importance of culture, the need for respecting its uniqueness, and its role in theologizing have been increasingly recognized in the recent decades. However, often, the role of culture in ethics or ethical formation has not received much attention, since ethical values and norms were considered universally valid. Considered against such a background, what Pope Francis says in Amoris Laetitia deserves our attention. The Pope says that though unity of teaching and practice is necessary in the Church, this does not preclude various ways of interpreting some aspects of that teaching or drawing certain consequences from it. "Each country or region, moreover, can seek solutions better suited to its culture and sensitive to its traditions and local needs. For 'cultures are in fact quite diverse and every general principle ... needs to be inculturated, if it is to be respected and applied"' (Francis 2016, para 3). Evidently, it is a general principle, and the Pope does not give specific norms as to how this process of inculturation is to be undertaken. For example, there are elements that are positive, and that can be inculturated without any difficulty, but there can be also elements that cannot be easily accepted or that have to be rejected. However, though it is a general principle only, it is highly commendable as it is an affirmation of the values in other cultures and of the possibility of dialogue on ethical issues.

\section{Initiatives for Doing Catholic Ethics in a Pluralistic Context}

In the recent decades, as Amaladoss says, there is a deeper conviction that, "All religions can facilitate salvific divine-human encounter, so that people belonging to other religions are saved, not merely in spite of, but because of practicing those religions ... " (Amaladoss 2011, p. 53). "Therefore, the only practical option before us is a third alternative: dialogue, positive relationship, collaboration and common pilgrimage and search for truth in view of the welfare, salvation and unity of the whole humanity ..." (Pathil 2014, p. 329). Thus, there have been a renewed interest in dialogue with religions and cultures and various initiatives were taken for dialogue in ethics, and for doing ethics in a pluralistic context. It is pointed out that religions should be an active participant in developing an ethics in a pluralistic context. We find that there is a resurgence of religion in public life, though sometimes this is experienced negatively, for example, as in the case of fundamentalism and religiously motivated terrorism, etc. However, the society has not become 'secular' and attempts to construct a secular ethics without any reference to religion or religious ethics will be futile. One noteworthy contribution is that of Hans Küng, who has written extensively on a global ethics (Küng et al. 1986; Küng 1996, 1997, 1998). He has highlighted some of the areas of consensus and common interest: Human wellbeing; maxims of basic humanity; a reasonable middle way; the golden rule; horizon for meaning and identification of a goal; concept of virtues and vices, etc. (Küng 1996, pp. 55-64).

Though not at an extensive level, there have been many initiatives in recent years to dialogue with ethics of other cultures and religions. In Search of a Universal Ethic outlines several areas of convergence in ethics and collaboration. In his books and articles, Yiu Sing Lúcás Chan has elaborated upon 
building bridges between Christian and Confucian ethics based on the virtue concept in both religions (Chan 2008, 2009, 2011, 2013, 2015). Osamu Takeuchi has brought out the relationship between the Japanese concept of $W a$ and Christian ethics (Takeuchi 2010). In its various conferences and publications, Catholic Theological Ethics in the World Church (CTEWC) has been giving special attention to ethics in a pluralistic context (Chan et al. 2016).

\section{Understanding Catholic and Hindu Approaches to Ecology and Sexuality}

What I am attempting here is to briefly present two areas of ethical interest as examples of possible dialogue and communication-ecology and sexuality. With regard to ecology the possibility of convergence is more, whereas regarding sexuality, the differences may be more conspicuous.

\subsection{Ecotheological Ethics}

At least from the time of the publication of Lynn White's "The Historical Roots of Our Ecological Crisis" (White 1967), Christianity has been accused of having been responsible for the ecological crisis. Environmental activists and philosophers sharply criticize that Christianity, assigning to the humans the role of 'subduing the earth' and 'dominating' it, promoted unbridled exploitation of the nature leading to the present crisis. Any attempt to consider the nature as sacred would be labelled as pantheism and idolatry. Based mainly on the interpretations given to the creation narratives, the Christian tradition developed an anthropocentric perspective, which considered the natural world "a resource for human utility and not as a functioning community of mutually supporting life-systems within which the human must discover its proper role" (Chethimattam 1991, p. 54). In this worldview, the nature has only a secondary importance (Tucker and Grim 2002, p. xxi). Creation, redemption, incarnation, resurrection, and parousia were interpreted in an anthropocentric way, though other perspectives also are present in the bible. However, Christian theology of ecology has drastically changed in recent decades. Creation stories, and other biblical passages are (re-) interpreted in such a way that a more important place is given to the eco-system, the earth, and nature as a whole. The encyclical letter of Pope Francis, Laudato Si', On the Care of Our Common Home (Francis 2015), reflects this renewed understanding and the urgency of the issue.

Hinduism has been a strong proponent of the sacredness of the earth and everything created. One of the fundamental cosmological insights of the Indian tradition regarding this world is that it is indwelt by the Lord of the Universe and hence it is sacred:

"Isavasyam idam sarvam yatkinça jagatyam jagat." (=This revolving world together with every minute particle in it is indwelt by the Lord) (Isa Upanișd, 1). As Nanditha Krishna, a noted Hindu expert on ecotheology in Hinduism, comments, "Hinduism believes that the earth and all life forms-human, animal and plant-are a part of Divinity. Man [sic] evolved out of these life forms and is a part of the creative process, neither separate nor superior." She further underscores that we should change our lifestyle and habits to simplify our material desires, without taking more than our reasonable share of resources (Krishna 2017, p. 223).

The same insight can be seen in the Bhagavad Gita: "Sarvasya çāham hrdi sannivişti." (=And I have inserted myself into the heart of everything) (Bhagavad Gita, 15:15). This is a basic Hindu conviction, and hence, nature is venerated by them, because they believe that "nature is a manifestation of the divine" (Krishna 2017, p. 11).

Brhadaranyaka Upanişd affirms this further, pointing out the simultaneous immanence and transcendence of the Divine:

He who is abiding in the earth, yet different from earth, ...

He who is abiding in the water, yet different from the water, ...

He who is abiding in the wind, yet different from the wind ... (Brhadaranyaka Upanișd, III, 7).

The Hindu vision affirms the sacredness not only of the human being, but everything in nature. The Hindu tradition reveres all life-human, non-human, plant, and animal. When humans imbibe this vision, they become servants of the Divine and all their actions, including those for protection of 
the world around them and all the beings therein, become acts of worship (Krishna 2017, p. 222). This calls for a new dimension in the human's relationship with nature: "Human life is sacred, as it is a sparkle of the Divine; so also is its environment. Since life and its setting are both sacred, we have to relate ourselves to humanity and nature on an equal footing" (Manickam 2008, p. 2).

Particularly of interest is the Hindu concept of the earth:

The Vedic attitude toward the earth springs from mankind's primordial experience of being on the one hand a guest, and on the other an offspring ... The earth is the foundation, the basis out of which emerges all that exists and on which everything rests. The earth is the basis of life and, when considered as divine being, she always occupies a special place among the Gods (Panikkar 1977, p. 120).

The worshipping of the earth is not adoration of a creature as an absolute, that is, it is not idolatry. In fact, it is the veneration of the highest value in the hierarchy of existence, for "undoubtedly this earth is the firstborn of being" (Satapada Brahmana, XIV, 1, 2, 10; Panikkar 1977, p. 121).

In the Hindu tradition, there is an underlying unity of all life, the world, and all that exists. The interconnectedness of all life and all creatures is affirmed by the scriptures (Bhattacharya 2006, p. 65).

Animals, in the Vedic vision, are not inferior creatures, but manifestations of gods on the lower scale of evolution compared to man. Animals like monkey, elephant, tiger, cow, bull, etc., occupy important places in the spectrum of gods. "Spiritually, there is no distinction between human beings and other forms of life. All forms, including plants and animals, are manifestations of god as limited beings (jivas). Even microorganisms are jivas, having souls of their own" (Cherian 2008, p. 191). The protection and worship of the cow symbolizes human responsibility to the sub-human world. This also stresses the reverence for all forms of life.

This attitude of reverence and gratitude to the earth and the whole cosmos in Hinduism shows us the possibility of working together to face the ecological crisis and to respond together to the spiritual inadequacy that many feel in the face of this crisis. There are differences in the basic faith vision and convictions, but a more critical re-evaluation of interpreting Hindu approach to nature as pantheistic and naturalistic will help us to understand better the richness of these traditions and to find common grounds to work together. Many have said the same regarding African religions, which have a reverential approach to the nature. Besides convincing us of the possibility of working together, this will also help us to re-discover our own eco-theology and eco-ethics, to reconsider the interpretations in the past, and to correct the imbalances.

The concept of nature and the approach of the two traditions may look different. However, we can notice that areas of convergence are identified today. Ecological ethics is an area where people belonging to different religions and cultures have begun to work together. There are publications in which scholars from various religions, including Christianity and Hinduism, have contributed. Some of the theological journals also have taken up the theme of ecotheology with the contribution of Hindu and Christian scholars. Recently, an inter-Asian workshop on the "Spirituality and Theology of Creation," under the leadership of Missio, Aachen, was conducted at Dharmaram Vidya Kshetram, Bangalore, India from 19-21 February 2019. This workshop was an attempt to look at the ecological issue from an intercultural, interreligious, and comparative perspective so as to promote the interreligious and intercultural dialogue on creation theology and environmental ethics. Scholars from Hinduism and Christianity presented papers and the papers will be published soon. ${ }^{5}$ Scholars from Hinduism and Christianity find great possibilities for working together on ecological issues and for developing together an ecological ethics. However, not much has been achieved so far to concretize the possibility of developing an ecotheolgical ethics together. The rise of fundamentalist ideas, promoted by some

5 The workshop brought together scholars from five religious traditions: Hinduism, Buddhism, Christianity, Islam, and Indigenous religions. For the announcement of the publication of the papers in German, please see Ibrahim, Isis, Shaji Kochuthara, and Klaus Vellguth, eds. forthcoming (Ibrahim et al. forthcoming). Finding a Home in Creation: Asian Creation Spiritualities in Dialogue. Ostfildern: Grünwald Verlag, (forthcoming), https://www.gruenewaldverlag.de/in-der-schoepfungheimat-finden-p-1447.html. English version of this book will be also published soon. 
groups including political parties, may be one of the main factors behind the reluctance to work together on such issues.

\subsection{Sexuality}

Christianity understands sexuality as good, willed by God, and as integral to the creative design of God. Based on the scripture, tradition, and theological developments, sexuality is understood to have basically three meanings or aspects: Love, procreation, and pleasure. Since most of the readers may be familiar with the Christian understanding of sexuality, I do not venture into a detailed discussion on this. Although these three are considered the basic aspects of sexuality, the understanding of the interrelationship among them has changed over time. For example, Augustine considered procreation as the primary good (of sexual relationship); for Aquinas, procreation was the primary end. From the time of Vatican II, the Catholic Church holds that procreation and love are the two inseparable purposes of marriage/marital sexuality. A theology of sexual pleasure is still in the phase of development. ${ }^{6}$ Moreover, marriage is understood as the only legitimate context of sexual relationship and sexual enjoyment. With this brief consideration, let us turn to Hinduism to see how it visualizes the meaning of sexuality.

"Nowhere have close relationships of religion and sex been displayed more clearly than in India and, with divine and human models of sexual activity, sacramental views of sex were abundantly illustrated" (Parrinder 1980, p. 5). The Hindu conception of a full life consists in the harmony of Dharma (righteousness), Artha (wealth), and Kama (sexuality/sexual desire). Although Dharma has primacy, it is equally emphasized that neither Artha nor Kāma is to be neglected by a normally by a person. ${ }^{7}$ Different approaches to sexuality can be identified in the Indian religious tradition. They may be perhaps broadly classified as follows: 8

\subsubsection{Mythical and Ritualistic Concept of Sexuality}

In this approach, sexuality is considered godly. This is especially depicted in the creation stories, where the work of creation is presented as the result of the sexual desire and sexual act of god/gods. The Upanişads contain descriptions of ritual intercourse. The stories of creation as the result of the sexual intercourse of Prajapati are examples (Brihadaranyaka Upanişad, 1.4). Brihadaranyaka Upanişad describes sexual intercourse as a ceremony. The woman is considered the consecrated place where sacrifice is to be performed (Brihadaranyaka Upanişad, 6.4). Moreover, the godheads are always represented with their female consorts (Kapoor 2002, p. 3). The stories of gods engaging in love and sexual intercourse with goddesses or humans also have as their underlying principle this approach to sexuality. This is in general the basis of fertility cults and rites. Here, what is emphasized more is the procreative dimension of sexuality, although the recreational dimension also is not lacking. The whole

6 Of the three aspects or meanings of sexuality, Catholic/Christian concept of sexual pleasure would be rather ambiguous. In the Catholic tradition, pleasure was not accepted as a good, end, or purpose [That is why I have presented it as one of the 'meanings' or 'aspects'. Rather, pleasure was often doubted as prone to lead humans to sin. At the maximum, pleasure would be recognised as a side-effect of the sexual act, which was basically oriented towards procreation. Greek philosophical concept, which did not accept pleasure as an end, was also influential in forming such an attitude towards pleasure in the Catholic tradition. However, we can see that the role of pleasure and its importance were acknowledged in negative terms, such as 'remedy for concupiscence', etc. In general, this can be said to be the Catholic concept of sexual pleasure until the mid-20th century. For the first time, positive value of conjugal sexual pleasure is accepted in an official document in 1951 (Pius XII 1951). A more positive view of sexual pleasure can be found in the works of contemporary theologians. For a detailed discussion, see Noonan (1986); Milhaven (1977, pp. 157-81); Census of India (2011a); Gudorf (1994); Brown (1998). My doctoral thesis was on the concept of sexual pleasure in the Catholic tradition: Kochuthara (2007).

7 Mahabharata, 12.167: Cfr. Geoffrey Parrinder, Sex in the World's Religions, 14. However, here kāma is more as a precondition for all the other puruşārthas. "Unless an individual has a desire to attain artha, to follow dharma, or to attain mokşa, he cannot have artha, dharma, or mokşa": Prasad (2008, p. 250).

8 We have to remember, however, that we cannot make a watertight division of different approaches. The origin and foundation of different approaches can be seen in the same puranas and in the stories of the same gods and goddesses. Similarly, elements of different approaches can be found in the same approach. I have attempted this classification taking into consideration their major emphasis. 
creation, fertility, and prosperity are considered to be the blessings of gods, who have engaged/engage in sexual activity. By worshipping the sexual powers of gods-which is often expressed by worshipping representation of the sexual organs of gods-and by engaging in ritual sexual intercourse, the devotees believe to attain fertility and prosperity.

\subsubsection{Mystical Concept of Sexuality}

The relationship and union between God and the human being/soul are symbolically presented in sensual and erotic language. The longing of the soul/human for God is described in vivid and explicit imageries of the sexual love and union of the devotee with the deity. Uninhibited description and narrative of the desire for the lover/deity, the pain of separation, and the joy in union are presented in sexual terms. Usually, the devotee is the female and the deity is the male. The Krssnaleela, especially the love-play of Krşna and Radha, in the Bhagavata Purana, is the best example for this. Other works in the Bhakti tradition also contain many such descriptions and stories. ${ }^{9}$ Sexuality here is the symbol of the highest union and intimacy that is possible between the bhakta and the deity. Thus, sexuality is raised into the realm of spirituality and mysticism.

\subsubsection{Tantric Concept of Sexuality}

In the Tantric system, in which mainly the Mother Goddess is worshipped, sexuality occupies a central role. Tantra, instead of a withdrawal, encourages the fullest acceptance of human desires and feelings, since they are the via media between the physical world and the inner reality. The aim is not the discovery of the unknown, but the realization of the real: "What is here, is elsewhere; what is not here, is nowhere" (Pande and Dane 2001, p. 80). That is, Tantra is not a philosophy of the denial of the world or the physical, but of their affirmation. The world and the body are means of attaining spiritual realization. The body is not the enemy of the soul; the matter and spirit are not two opposing forces fighting with each other. The body is the means, through which alone the human can come to spiritual fulfilment. Spiritual powers are hidden in the body itself. Sex is a means of awakening the kundalini, of joining the female and male principles in the body, through which alone the spiritual powers of the body will be ultimately released and realized. Hence, sexual union becomes a ritual for spiritual realization.

\subsubsection{Kāmaśāstra}

This is the science of love and sex. This can be said to be the Indian sexology. Elements of Ayurveda and eugenics also can be seen in this. Kāmaśāstra is concerned merely to teach the means and manner through which man may enjoy kāma the best (Kapoor 2002, p. 35). Kāma, although often understood as sexual pleasure, "denotes the whole range of possible experience within the sphere of love, sex, sensual gratification and delight. Kāma is wish, desire, carnal gratification, lust, love, and affection" (Zimmer 1990, p. 145). Kāmasūtra by Vatsyayana is the most well-known work of Kāmaśāstras. Kāmaśāstras deal with the sex and man-woman relationship. Their chief concern is to help the human being attain pleasure. They also speak about family and the importance of the progeny, but what they underscore is the dimension of man-woman relationship and the attainment of pleasure in their union.

These different approaches to sexuality existed side by side in Hinduism, with some traditions or sects giving more importance to a particular approach or adopting only one. However, there was no attempt from a particular sect or tradition to condemn other approaches to sexuality. Different approaches were accepted as equally valid and as having their own value.

Comparing both the Catholic and Hindu concepts of sexuality, we can identify that the basic meanings are the sam; namely, love, procreation, and pleasure. However, the way they are understood

9 Among love poetry based on the love of Krşna and Radha, Gita Govinda, the works of Chandi Das, of Chaitanya (16th century), of the Ālvārs, etc. are among the most popular. Chaitanya used to dress himself as Kŗ্̧na and Radha. 
and practiced, and the understanding of the interrelationship among them, are different. This does not mean that there is no possibility of dialogue or convergence. For example, especially for a better understanding of the positive value of sexual pleasure, Catholic theology can be helped by the Hindu approach to sexual pleasure. However, such initiatives need more profound dialogue. Moreover, it is also important to situate the values in sexual morality in the overall vision of values in human life.

\section{Concluding Remarks and A Few Basic Considerations}

1. Doing ethics in a pluralistic world is not about constructing new ethical system or principles or norms; that is, it is not about inventing a new ethic-that will become just an addition to different ethical systems already existing. Doing ethics in a pluralistic world is about understanding the ethics and approaches of each other; believing in the sincerity of each religion and culture in seeking the good; appreciating them; understanding areas of agreement; strengthening those areas of agreement; understanding the differences; and reflecting together on the differences without being judgmental.

2. Doing ethics in a pluralistic context is not succumbing to 'relativism'. It does not mean taking a position that there is no universally valid ethical norm or that any norm can be changed at any time. It is about understanding and appreciating the basic values behind the norms and understanding those values even when their expressions in the particular context through norms are different.

3. There can be areas on which agreement can be rather easy, whereas agreement on certain areas and issues may be difficult, which may demand more dialogue and critical evaluation together. What is important is how we are able to collaborate. If we wait until perfect consensus is arrived at before working together, we may never be able to collaborate. Instead, if we begin to collaborate on issues on which we agree, we may be able to understand each other better. However, in that process, we may learn to dialogue better even on areas of disagreement.

4. Attempts to develop a pluralistic ethics are founded on a basic trust in the goodness and good will of all, namely, all seek human wellbeing, all seek to do good, and avoid evil. ${ }^{10}$ However, the concept of what is good and what is evil, especially in concrete issues, may differ. This difference also depends on the differences in the anthropological vision, world vision, and theological vision. This calls for an ongoing dialogue with each, not for mutual condemnation and fighting with each other. Uniformity cannot be set as the goal; relativism also cannot be a solution. Instead, a searching together for what is more humanizing for human beings individually and collectively can be undertaken.

5. Doing ethics in a pluralistic context demands a serious study, research, and search in the scriptures, traditions, and works by recognized scholars of each religion.

6. Each religion and culture may have various traditions and various opinions on a particular concept or ethical issue, sometimes conflicting and contradictory. There may be ethical norms that are not conducive to the wellbeing of the person and society. They need to be corrected. However, attempts to correct or change the ethical perspective, if at all they are needed, shall focus first of all inviting their attention to internal differences, or conflicts, and thus to understand the real value and ensuing ethical norm. If this possibility is not there, a critical evaluation of the proper perspective in light of the views of others may be requested, but without claiming any superiority.

7. Humility is one of the most fundamental virtues in dialogue. No one, including 'we', possesses the full truth and its understanding. God is beyond the full comprehension of everyone, including our own. We can help others in understanding and experiencing God better; similarly, others also

10 This is the fundamental principle of natural law according to Thomas Aquinas. Cfr. Thomas Aquinas, Summa Theologiae, I-II, q. 94. 
can help us. We do not possess the fullness of truth; perhaps others too do not possess it. We are seekers in the same path, seekers seeking together, learning from each other, helping each other to understand and experience the fullness of truth. This basic humility gives us the possibility of realizing our own limitations and incompleteness, and to understand the richness of others.

8. Plurality is a given-ness of life, and it is going to remain so. What matters is our approach to plurality, how we live together enriching each other and being enriched by others. Human existence is basically co-existence. We need to face together the ethical challenges of today: Violence, intolerance, injustice, poverty, suffering of the innocent, ecological crisis, terrorism, crisis of democracy and political leadership, etc. Any ethical issue anywhere in the world is or should be felt an issue in any other part of a globalized world, since humanity is interconnected, and since it must be approached as an issue about the basic dignity of the human person. What we need is a concerted effort to solve it in solidarity with others, in the spirit of dialogue, in humility and openness to others, and openness to the Spirit who is active in everyone, in every religion and culture.

9. Having said all these, we cannot claim that a clear theoretical framework is already there for a pluralistic ethics. For that, scholars from various traditions have to come together for dialogue. Only through such a dialogue even a framework for a pluralistic ethics can be developed.

Funding: This research received no funding.

Conflicts of Interest: The author declares no conflicts of interest.

\section{References}

Amaladoss, Michael. 2011. The FABC Theology of Religions. In Harvesting from the Asian Soil: Towards an Asian Theology. Edited by Vimal Tirimanna. Bangalore: Asian Trading Corporation, pp. 53-66.

Bhattacharya, Swasti. 2006. Magical Progeny, Modern Technology. A Hindu Bioethics of Assisted Reproductive Technology. New York: State University of New York Press.

Brown, Peter. 1998. The Body and Society. Men, Women and Sexual Renunciation in Early Christianity. New York: Columbia University Press.

Census of India. 2011a. Religion Census 2011. Available online: https://www.census2011.co.in/religion.php and https://pib.gov.in/newsite/printrelease.aspx?relid=126326. (accessed on 18 December 2019).

Census of India. 2011b. Language. According to This, There are 19569 Dialects. Available online: http: //censusindia.gov.in/2011Census/C-16_25062018_NEW.pdf (accessed on 18 December 2019).

Chackalackal, Saju. 2016. Christianity's Encounter with the Spirit and Genius of India: An Unaccomplished Mission. In Church on Pilgrimage: Trajectories of Intercultural Encounter. Edited by Kuncheria Pathil. Bengaluru: Dharmaram Publications, pp. 398-429.

Chan, Yiu Sing Lúcás. 2008. Bridging Christian Ethics and Confucianism through Virtue. Chinese Cross Currents 5: 74-85.

Chan, Yiu Sing Lúcás. 2009. As West Meets East: Reading Zunzi's 'A Discussion of Rites'. In 'Ahme nach was du vollziehst.' Positionsbestimmungen zum Verhältnis von Liturgie und Ethik. Edited by Martin Stuflesser and Stephan Winter. Regensburg: Friedrich Pustet KG, pp. 101-20.

Chan, Yiu Sing Lúcás. 2011. Bridging Christian and Confucian Ethics: Is the Bridge Adequately Catholic and Asian? Asian Christian Review 5: 49-73.

Chan, Yiu Sing Lúcás. 2013. Catholic Theological Ethics: Some Reflections on the Asian Scenario. In Moral Theology in India Today. Edited by Shaji George Kochuthara. Bangalore: Dharmaram Publications, pp. 101-21.

Chan, Yiu Sing Lúcás. 2015. The Ten Commandments and Beatitudes: Biblical Studies and Ethics for Real Life. Bengaluru: Dharmaram Publications. First Published from Rowman \& Littlefield Publishers, 2012.

Chan, Yiu Sing Lúcás, James F. Keenan, and Shaji George Kochuthara, eds. 2016. Doing Asian Theological Ethics in a Cross-Cultural and an Interreligious Context. Bengaluru: Dharmaram Publications.

Cherian, Joby. 2008. Vedic Ethos and Environmental Concerns. Journal of Dharma 33: 185-96.

Chethimattam, John B. 1991. Ecology and Environment in Catholic Perspective. Kristu Jyoti 7: 46-59. 
Christiansen, Drew. 2018. Commentary on Pacem in Terris. In Modern Catholic Social Teaching: Commentaries and Interpretation, 2nd ed. Edited by Kenneth R. Himes. Washington, DC: Georgetown University Press, pp. 226-52.

Curran, Charles E., ed. 2003. Changes in Official Catholic Moral Teaching. New York: Paulist Press.

Economic Times. 2018. Women of All Ages can Enter Sabarimala Temple, Rules Supreme Court. September 29. Available online: https://economictimes.indiatimes.com/news/politics-and-nation/supreme-court-allowswomen-to-enter-sabarimala-temple/articleshow/65989807.cms (accessed on 10 October 2018).

Eilers, Franz-Josef, ed. 1997. For All the Peoples of Asia: Vol. 2: Federation of Asian Bishops' Conferences Documents from 1992 to 1996. Quezon City: Claretian Publications.

Francis. 2015. Laudato Si'. Available online: http://w2.vatican.va/content/francesco/en/encyclicals/documents/ papa-francesco_20150524_enciclica-laudato-si.html (accessed on 18 December 2019).

Francis. 2016. Amoris Laetitia. Available online: https://w2.vatican.va/content/dam/francesco/pdf/apost_ exhortations/documents/papa-francesco_esortazione-ap_20160319_amoris-laetitia_en.pdf (accessed on 18 December 2019).

Gudorf, Christine E. 1994. Body, Sex and Pleasure. Cleveland: The Pilgrim Press.

Gula, Richard M. 1989. Reason Informed by Faith: Foundations of Catholic Morality. New York: Paulist Press.

Henn, William. 1987. Pluralism. In The New Dictionary of Theology. Edited by Joseph A. Komonchak, Mary Collins and Dermot A. Lane. Dublin: Gill and Macmillan, pp. 770-72.

Ibrahim, Isis, Shaji Kochuthara, and Klaus Vellguth, eds. (forthcoming). Finding a Home in Creation: Asian Creation Spiritualities in Dialogue. Ostfildern: Grünwald Verlag, Available online: https://www.gruenewaldverlag.de/ in-der-schoepfung-heimat-finden-p-1447.html (accessed on 18 December 2019).

International Theological Commission. 2009. In Search of a Universal Ethic: A New Look at the Natural Law. Available online: http://www.vatican.va/roman_curia/congregations/cfaith/cti_documents/rc_con_cfaith_ doc_20090520_legge-naturale_en.html (accessed on 1 October 2019).

John Paul II. 1998. Fides et Ratio. Encyclical Letter on the Relationship between Faith and Reason (14 September 1998). Available online: http://w2.vatican.va/content/john-paul-ii/en/encyclicals/documents/hf_jp-ii_enc_ 14091998_fides-et-ratio.html (accessed on 12 December 2019).

Kapoor, Subodh. 2002. Encyclopaedia of Indian Heritage, Vol. 45: Vatsyayana. New Delhi: Cosmo Publications.

Keenan, James F. 2007. Towards a Global Vision of Catholic Moral Theology. Reflections on the Twentieth Century. Bangalore: Dharmaram Publications, pp. 101-45.

Kochuthara, Shaji George. 2007. The Concept of Sexual Pleasure in the Catholic Tradition. Roma: Editrice Pontificia Università Gregoriana.

Kochuthara, Shaji George. 2011. Context and the Future of Theological Ethics: The Task of Building Bridges. In Catholic Theological Ethics: Past, Present, and Future: The Trento Conference. Edited by James F. Keenan. Maryknoll, New York: Orbis Books, pp. 296-306.

Krishna, Nanditha. 2017. Hinduism and Nature. Gurgaon: Penguin Books.

Küng, Hans. 1996. Global Responsibility: In Search of a New World Ethic. New York: Continuum.

Küng, Hans. 1997. A Global Ethic for Global Politics and Economics. London: SCM Press.

Küng, Hans. 1998. A Global Ethic for Global Politics and Economics. New York: Oxford University Press.

Küng, Hans, Josef van Ess, Heinrich von Stietencron, and Heinz Bechert. 1986. Christianity and World Religions: Paths to Dialogue. Maryknoll, New York: Orbis Books.

Kusumalayam, John. 2008. Human Rights: Individual or/and Group Rights. Bandra, Mumbai: St. Pauls.

Manickam, Thomas. 2008. Holistic Ethics and Global Environmental Crises. Journal of Dharma 33: 111-32.

Milhaven, John Giles. 1977. Thomas Aquinas on Sexual Pleasure. Journal of Religious Ethics 5: 157-81.

Noonan, John T. 1986. Contraception. Cambridge and London: The Belknap Press of Harvard University Press.

Noonan, John T., Jr. 1993. Development in Moral Doctrine. Theological Studies 54: 662-77. [CrossRef]

Noonan, John T., Jr. 2005. A Church that can and cannot Change: The Development of Catholic Moral Teaching. Notre Dame: University of Notre Dame Press.

O'Collins, Gerald. 2011. Rethinking Fundamental Theology. Oxford: Oxford University Press.

Painadath, Sebastian. 2016. Christianity's Relationship with Other Religions: Emerging New Paradigms. In Church on Pilgrimage: Trajectories of Intercultural Encounter. Edited by Kuncheria Pathil. Bengaluru: Dharmaram Publications, pp. 467-84.

Pande, Alka, and Lance Dane. 2001. Indian Erotica. New Delhi: Roli Books. 
Panikkar, Raimundo. 1977. The Vedic Experience. Mantramañjari: An Anthology of the Vedas for Modern Man and Contemporary Celebration. Delhi: Motilal Banarsidass Publishers, [Reprint 2001].

Parrinder, Geoffrey. 1980. Sex in the World's Religions. New York: Oxford University Press.

Pathil, Kuncheria. 2014. Pluralism, Dialogue and Communion. In Revisiting Vatican II: 50 Years of Renewal, Vol. I: Keynote and Plenary Papers of the DVK International Conference on Vatican II. Edited by Shaji George Kochuthara. Bangalore: Dharmaram Publications, pp. 322-34.

Pius XII. 1951. Address to Midwives (29 October 1951). AAS 43: 835-54.

Plathottam, George. 2009. Homosexuality: Faulty, Flawed Debates. Indian Currents, July 13-19, 32-33.

Prasad, Rajendra. 2008. A Conceptual-Analytic Study of Classical Indian Philosophy of Morals History of Science, Part I. In Philosophy and Culture in Indian Civilization, Vol XII. New Delhi: Concept Publishing Company.

Singh, Kuwar. 2018. India's Supreme Court Strikes Down a Colonial-era Adultery Law. Quartz India. September 27. Available online: https://q.com/india/1404196/adultery-no-longer-crime-in-india-rules-supreme-court/ (accessed on 10 October 2018).

Takeuchi, Osamu. 2010. The Heart of Wa and Christian Ethics. Asian Horizons 4: 114-27.

The Guardian. 2019. 'Historic' Day as India Outlaws 'Triple Talaq' Islamic Instant Divorce. Available online: https://www.theguardian.com/world/2019/jul/31/triple-talaq-india-hails-historic-day-as-parliamentoutlaws-islamic-instant-divorce (accessed on 12 December 2019).

Thomas Aquinas. 1947. Summa Theologiae, I-II. Translated by Dominican Fathers of the English Province. Notre Dame: Christian Classics.

Times of India. 2010. Live-in Relationship, Pre-marital Sex not an Offence: SC. Available online: http:/timesofindia.indiatimes.com/india/Live-in-relationship-pre-marital-sex-not-an-offence-SC/ articleshow/5716545.cms (accessed on 23 March 2010).

Tracy, David. 1975. Blessed Rage for Order: The New Pluralism in Theology. New York: Seabury Press.

Triple Talaq in India. n.d. Available online: https://en.wikipedia.org/wiki/Triple_talaq_in_India (accessed on 12 October 2019).

Tucker, Mary Evelyn, and John Grim. 2002. Series Foreword. In Jainism and Ecology: Non-violence in the Web of Life. Edited by Christopher Key Chapple. Cambridge: Harvard University Press for the Centre for the Study of World Religions.

UCA.News. 1998. Message of Special Assembly of Synod of Bishops for Asia. May 14. Available online: post_name=/1998/05/14/message-of-special-assembly-of-synod-of-bishops-for-asia\&post_id=1039 (accessed on 2 October 2019).

Universal Declaration of Human Rights. n.d. Available online: https://www.un.org/en/udhrbook/pdf/udhr_ booklet_en_web.pdf (accessed on 12 December 2019).

Vaidyanathan, A. 2018. “Adultery Not a Crime, 'Husband Not Master of Wife,' Says Supreme Court”. NDTV. September 27. Available online: https://www.ndtv.com/india-news/adultery-law-is-arbitrary-says-chiefjustice-dents-the-individuality-of-women-1922922 (accessed on 10 October 2018).

Vatican II. 1965. Nostra Aetate. Available online: http://www.vatican.va/archive/hist_councils/ii_vatican_council/ documents/vat-ii_decl_19651028_nostra-aetate_en.html (accessed on 18 December 2019).

White, Lynn, Jr. 1967. The Historical Roots of Our Ecological Crisis. Science 155: 1203-7. [CrossRef] [PubMed]

Zimmer, Heinrich. 1990. Philosophies of India. Edited by Joseph Campbell. Delhi: Motilal Banarsidass, reprint 2005.

(C) 2019 by the author. Licensee MDPI, Basel, Switzerland. This article is an open access article distributed under the terms and conditions of the Creative Commons Attribution (CC BY) license (http://creativecommons.org/licenses/by/4.0/). 